\title{
Comparison of a Perpetual and PD Inventory Control System with Smith Predictor and Different Shipping Delays Using Bicriterial Optimization and SPEA2
}

\author{
Ewelina Chołodowicz, Przemysław Orłowski
}

Zachodniopomorski Uniwersytet Technologiczny w Szczecinie, ul. Sikorskiego 37, 70-313, Szczecin

\begin{abstract}
Inventory optimization is critical in inventory control systems. The complexity of real-world inventory systems results in a challenging optimization problem, too complicated to solve by conventional mathematical programing methods. The aim of this work is to confront: a perpetual inventory system found in the literature and inventory system with PD control and Smith predictor proposed by the authors. To be precise, the two control systems for inventory management are analyzed with different shipping delays and compared. With regard to complexity of the proposed control system, we use a SPEA2 algorithm to solve optimization task for assumed scenario of the market demand. The objective is to minimize the inventory holding cost while avoiding shortages. A discrete-time, dynamic model of inventory system is assumed for the analysis. In order to compare the results of systems, Pareto fronts and signal responses are generated.
\end{abstract}

Keywords: inventory control systems, optimization, perpetual inventory system, multi-objective optimization, SPEA2, PD control, Smith predictor, inventory

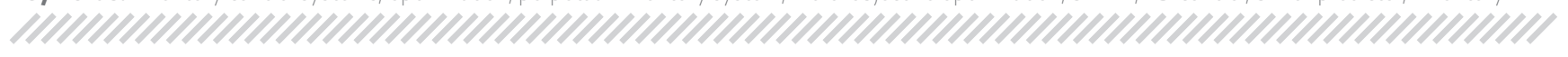

\section{Introduction}

Increasing dimension of inventory management requires advanced methods to reduce maintenance costs. As a result of the emergence of complex inventory control systems, more and more scientist began to use the methods of multi-criteria optimization. Pareto-based techniques were proposed in 1993 and 1994, e.g., MOGA [1], NPGA [2] and NSGA [3]. One of the most effective algorithms, used in multi-criteria problems, is the Strength Pareto Evolutionary Algorithm (SPEA) proposed in [4]. SPEA has shown very good performance in comparison to other multi-objective evolutionary algorithms [5]. Furthermore, improved version of SPEA has also been created. It is called SPEA2 and is presented in [6]. The improved Strength Pareto Evolutionary Algorithm is one of the most important multi-objective evolutionary algorithms that use elitism approach and therefore it has been used in recent studies: [7-12].

\section{Autor korespondujący:}

Ewelina Chołodowicz, cholodowicz.ewelina@gmail.com

Artykuł recenzowany

nadesłany 01.08.2016 r., przyjęty do druku 22.08.2016 r.
Inventory optimization means maintaining a certain level of inventory that would eliminate the out-of-stock situations and at the same time would provide as low as possible holding costs. In a nutshell, this is all about maintaining balance between demand and supply. Every inventory system faces the challenge of matching its supply volume to customer demand. How well control system manages this complex challenge has a profound impact on inventory profitability. Due to the necessity for effective inventory management inventory control systems have been developed. The two classic systems for managing customer demand are a periodic and a perpetual system [13]. A perpetual inventory system is a superior to the older periodic inventory system because it keeps continual track of sales and inventory levels which helps to prevent stock-outs - this is its advantage.

There has been an growing interest in solving inventory management problem. Before control systems, a lot of inventory models have been invented: [14-16]. More and more works have been focusing upon creating new or modified inventory control systems: [17-24]. Issues of a similar problem dimension, but associated with congestion control in computer networks, are presented in [25].

Due to occurring variance amplifications of order quantities in inventory systems, called the bullwhip effect [26], it is necessary to use special methodology to eliminate such a situation. This extremely negative phenomenon had gave rise to range of methodologies used to this day and is indispensably connected to the stability of supply chains which is investi- 
gated in [27]. Conducted research in [27] quantifies the effect of these variations on system stability and presents mechanism with work in progress (WIP) position. On the other hand, in [17] is proposed methodology for time-varying delay based on Smith predictor. However, in $[26,27]$ it is suggested a general replenishment rule that can reduce variance amplification significantly by control theoretic approach, which integrated different forecasting methods into the order-up-to system. To our knowledge, order-up-to systems usually result in the bullwhip effect [26]. An order-up-to policy is optimal in the sense that is minimizes the expected holding and shortage costs [28]. As far as methods for bullwhip effect reduction are concerned, $\mathrm{H}$-infinity control methodology minimizes the worst case effects of the external demand fluctuations on the performance of the system [29]. The application of this method requires that the transportation and production lead times are known and constant, but also can be used with satisfactory results with time-varying delays. H-infinity policy applies the filtering techniques and optimizes local inventory costs while avoiding the bullwhip effect.

In order to make a fair comparison between a classical stockbased order-up-to policy and PD with Smith predictor inventory control system we apply work-in-progress to account for the destabilizing effect in the perpetual inventory system. The aim of this work is to analyze and compare work of systems with different shipping delays: Perpetual Inventory System with adaptive order level and work-in-progress mechanism proposed by literature and Proportional-derivative Inventory Control System with Smith predictor and adaptive reference stock level proposed by the authors. In other words, this work is comparison between our PD-Smith-based methodology which was used in [21] for time-varying delay (in this work is examined for time-invariant systems) and classical order-up-to policy used mostly for time-invariant systems. Parameters were selected for all control systems structures through solving optimization tasks for a specific scenario of variable market demand using the Strength Pareto Evolutionary Algorithm 2 (SPEA2) in MATLAB/Simulink. In this article, we mainly want to show differences of results gained through solving optimization task using SPEA2 and performance for two control inventory systems and different shipping delays. The objective of inventory optimization is to maintain optimal inventory levels depending on demand and to minimize inventory holding cost while avoiding shortages [30]. In [31] Pareto-based meta-heuristic algorithm are used to solve the bi-objective inventory models. The first objective function aims to minimize the total cost of the system, which consists of holding cost, ordering cost and shortage cost and the second objective function, maximizes the service level through minimizing the cumulative distribution of the demands [31].

In this paper, the results for both systems are compared using a bi-objective optimization. In order to compare the

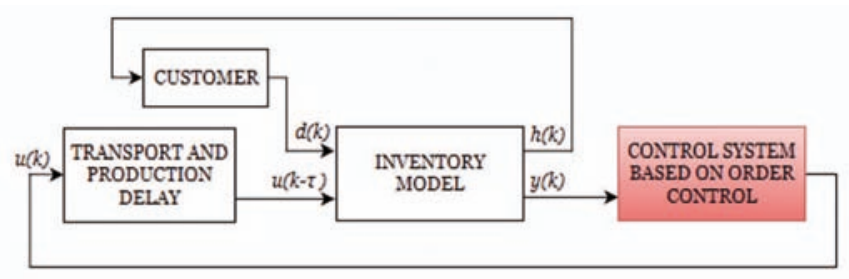

Fig. 1. Block diagram of inventory system with control system Rys. 1. Schemat blokowy systemu magazynowego z układem sterowania results, several numerical examples are generated and the results are analyzed on the basis of generated plots and tables.

\section{The Mathematical Model of Inventory}

The number of products that could potentially be sold from the store is modelled as a certain, unknown in advance limited function of time: $0 \leq d(k) \leq d_{\max }$. Where $d_{\max }$ is the maximum number of products sold per unit of time. Instantaneous values of $d(k)$ fluctuate in time and depend on the market demand. Demand for the products is generally variable in time. The number of products purchased from the inventory $h(k)$ depends on the demand, as well as the available stocks $y(k)$ and following inequalities are held:

$$
0 \leq h(k) \leq d(k) \leq d_{\max }, \quad 0 \leq y(k) \leq y_{\max }
$$

If the quantity of products in stock at moment $k$ is sufficiently large, it means that: $d(k)=h(k)$.

From the standpoint of controlling the flow of goods, it is important to maintain certain stock in the inventory, regardless of transient changes in customer demand, so as to avoid a situation in which the magazine is empty or the quantity of the stored products will be excessive, or even exceeds the storage capacity $y_{\max }$.

The product quantity stored in the inventory at moment $k$, called the stock, is therefore given as follows:

$$
y(k)=y(k-1)+u(k-\tau)-h(k)
$$

$\tau$ - the time required to deliver ordered products to the inventory.

The delay is known $\tau$ and this model is a linear, stationary and discrete with signals saturations. The block diagram of the analysed system is shown in Fig. 1. The system consists of three main blocks: transport and production delay, inventory model and control system based on order control.

\section{The Control Systems Definitions}

There are many different ways to keep control of the inventory but in every inventory control system, it is necessary to determine when and how much to order. Scientific methods for inventory control can give a significant competitive advantage. Control system has to order the certain amount of products at a certain time with a view to market demand and current inventory level. Inventory control means that all stocks of products are promptly and properly ordered, issued, preserved and accounted in the best interest of an entity that manages its inventory.

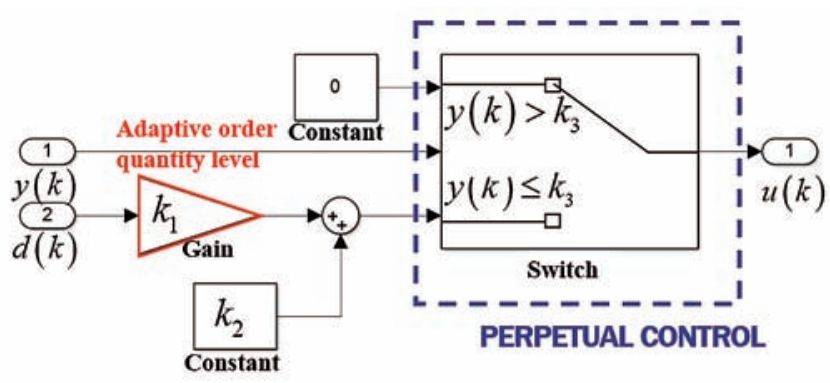

Fig. 2. A block diagram of Perpetual Inventory control system with adaptive order level

Rys. 2. Schemat blokowy ciąłłego systemu sterowania magazynem z adaptacyjnym poziomem zamówień 
It is essential to create a mathematical description of investigated two control systems:

\section{A) Perpetual Inventory System with adaptive order level}

A Perpetual Inventory System is also known as "Automatic Inventory System". A perpetual system keeps records of the amount in storage, and it replenishes when the stock drops to certain level $k_{3}$.

The reorder point - threshold, inventory content critical value, is fixed, but review period, order quantity and maximal inventory level are variable (max inventory level depends on demand). $k_{1}$ together with a factor $k_{2}$ make an affine function of maximal inventory capacity depending on market demand, given in the following form:

$$
u(k)=\left\{\begin{array}{ccc}
0 & \text { for } & y(k)>k_{3} \\
k_{1} d(k)+k_{2} & \text { for } & y(k) \leq k_{3}
\end{array},\right.
$$

where: $k_{3}$ - reorder point.

In order to make a fair comparison between a classical stock-based order-up-to policy and PD with Smith predictor inventory control system we supplement the control law (3) of the perpetual inventory system with work-in-progress term to provide for the controller data about past orders which are not delivered to the inventory yet. The system will be denoted as A' and the control law is described in the following way:

$u(k)=\left\{\begin{array}{cc}0 & \text { for } y(k)+\sum_{i=1}^{\tau} u(k-i)>k_{3} d(k) \\ k_{1} d(k)+k_{2}-\sum_{i=1}^{\tau} u(k-i) & \text { otherwise }\end{array}\right.$

\section{B) Proportional-derivative Inventory Control System with Smith predictor and adaptive reference stock level}

The structure shown in Fig. 3 - the control system is based on a classical structure with Smith predictor. It is a kind of a predictive controller, which was developed for control systems, which are characterized by long and inevitable delays. Its structure is based on implementations of the model without delay and with delay. Based on the control concepts for systems with delays using a Smith predictor it is assumed that an estimated model of the system without delay is given in the form:

$$
\hat{y}_{p}(k)=\hat{y}_{p}(k-1)+u(k-1)-h(k)
$$

Model of discrete-time PD controller for error $\varepsilon(k)$ of model without delay is given in the following form:

$$
u(k)=k_{2} \varepsilon(k)+k_{3} \varepsilon(k-\varepsilon k-1
$$

where:

$$
\varepsilon(k)=y_{r e f}(k)-\hat{y}_{p}(k)
$$

It is assumed that the reference value of stocks $y_{\text {ref }}(k)$ is a linear function of the demand given in the form of:

$$
y_{r}(k)=k_{1} d(k)
$$

Block diagram of the control system is shown in Fig. 3. The variables $k_{1}-k_{3}$ are parameters of the control system.

Due to the similarity between the considered class of systems and engineering processes, it is a natural choice to apply control-theoretic methods in the design and analysis of strategies governing the flow of goods.

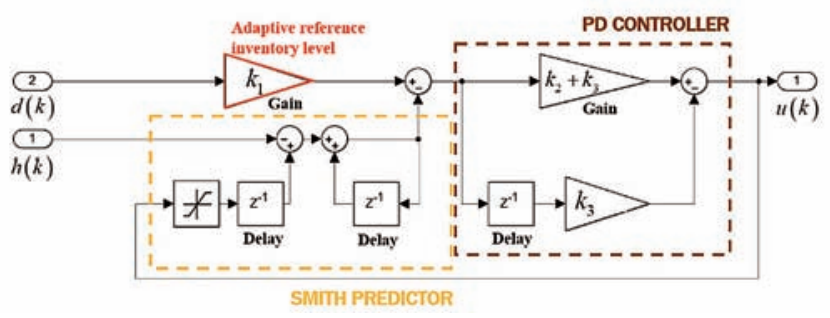

Fig. 3. A block diagram of Proportional-derivative Inventory control system with Smith predictor and adaptive reference stock level

Rys. 3. Schemat blokowy systemu sterowania magazynem z regulatorem proporcjonalno-różniczkującym oraz predyktorem Smitha z adaptacyjnym referencyjnym poziomem zapasów

\section{Bicriterial optimization and SPEA2}

Consider, the problem of finding the optimal values of the parameters $k_{i}, i=1,2,3$ of a dynamic system with fixed structure from Figs. 2-3. In the case of the inventory system, cost functions can be defined by the following relations:

$$
\begin{gathered}
j_{1}=\frac{1}{N} \sum_{k=\tau}^{N}[d(k)-h(k)] \\
j_{2}=\frac{1}{N} \sum_{k=\tau}^{N} y(k)
\end{gathered}
$$

where: $\tau$ - the time required to deliver ordered products to the inventory, $N$ is the length of the time horizon.

The equation (9) represents a lost opportunity to make sales. In turn, the expression (10) concerns use of space in the inventory.

The objective is represented as the following vector:

$$
\mathbf{j}=\left[j_{1}, j_{2}\right]
$$

For the model described by relationships (1)-(2) and the control systems described by equations (3)-(8) and a quality indicator in the form of (9)-(11) the optimization problem can be defined in the following form:

$$
\min _{\mathrm{k}} \mathbf{j}
$$

Where optimization variables and constraints are dependent on the controller structure:

$$
\mathbf{k}=\left[k_{1}, k_{2}, k_{3}\right], k_{1} \geq 0, k_{2} \geq 0, k_{3} \geq 0
$$

The improved Strength Pareto Evolutionary Approach (SPEA2) is chosen to perform the control system optimization resulting in the final analysis and comparison. SPEA is an extension of the Genetic Algorithm for multiple objective optimization problems. SPEA2 has an external archive consisting of the previously found non-dominated solutions. It is updated after every generation and for each solution a strength value is computed [28]. An archive of the non-dominated set is maintained separate from the population of candidate solutions used 


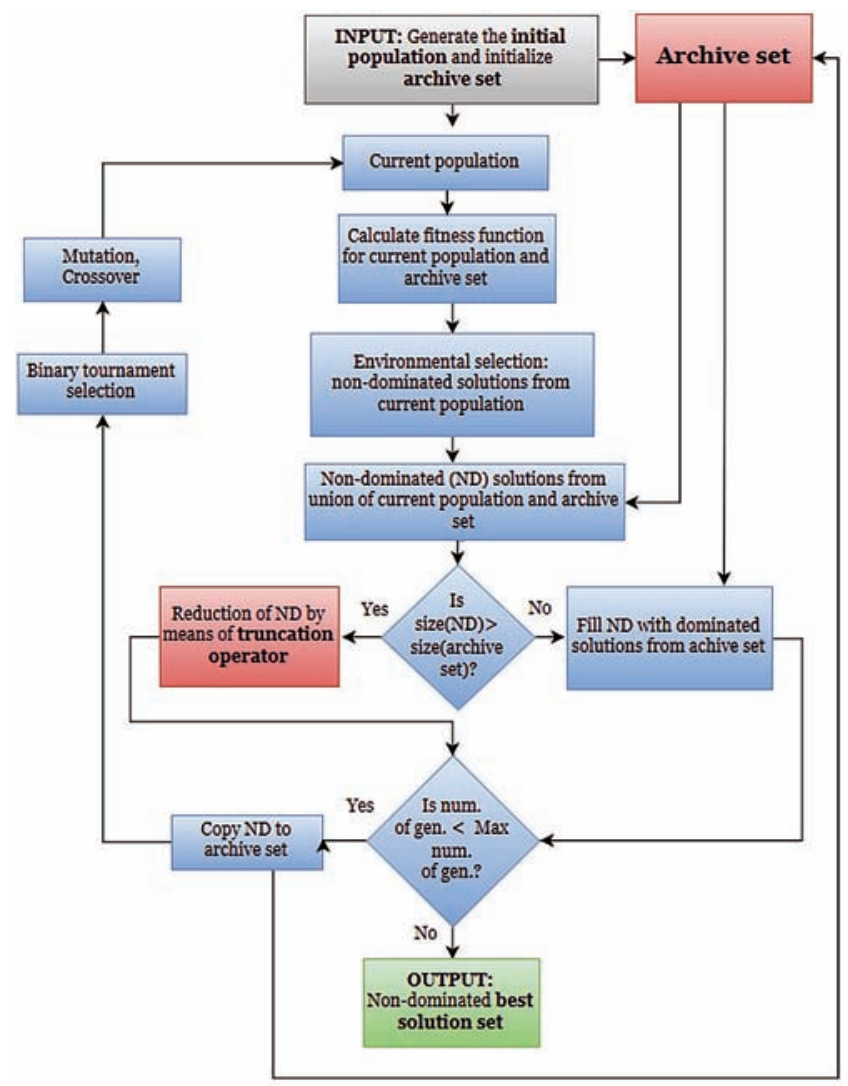

Fig. 4. Flow chart of SPEA2 algorithm

Rys. 4. Schemat blokowy algorytmu SPEA2

in the evolutionary process, providing a form of elitism. Due to potential weaknesses of SPEA, the improved version - SPEA2 has better fitness assignment scheme, more precise guidance of the search and a new archive truncation methods [6]. To avoid situations where population members dominated by the same members of the archive have the same fitness value, SPEA2 takes into account both the number of dominating and dominated solutions in computing the raw fitness of a solution. The objective of the algorithm is to locate and maintain a front of

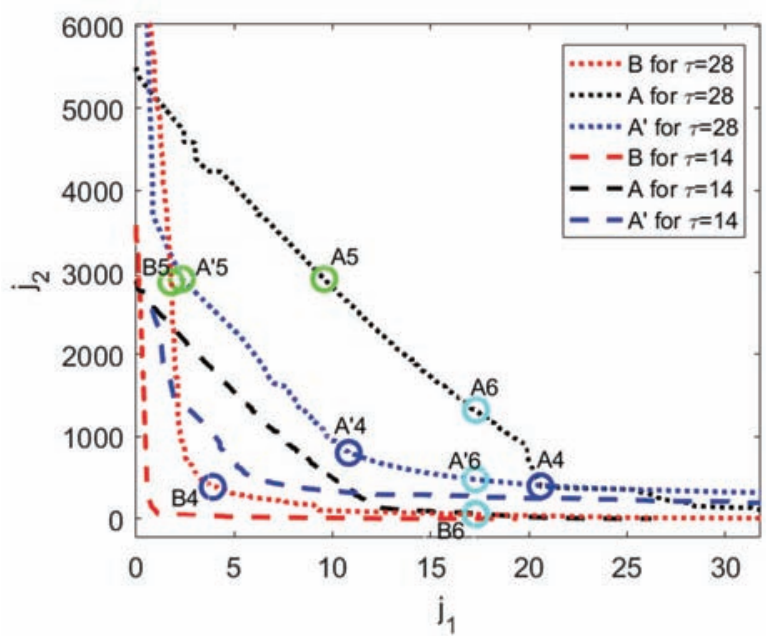

Fig. 5. Pareto front and selected points for inventory control system for two different delays

Rys. 5. Front Pareto oraz wybrane punkty dla systemu sterowania magazynem z dwoma różnymi opóźnieniami non-dominated solutions - set of Pareto optimal solutions. The flow chart which shows the steps of SPEA2 can be seen in Fig. 4.

\section{Simulation Research and Analysis}

In this section the results of computer simulations and comparative analysis is presented. The structures of control systems in Figures 2 and 3 are applied. The main purpose of this section is to compare the optimization results for different time delays for two different control structures: Perpetual Inventory System with adaptive order level A, Perpetual Inventory System with adaptive order level with work-in-progress mechanism A' which stems from literature and Proportional-derivative Inventory Control System with Smith predictor and adaptive reference stock level proposed by authors. Results for A - PIS-AOL control system are marked by black lines, A' - PIS-AOL' by blue lines and whereas for B - PDIS-SP-ARSL control system are marked by red line.

With a view to simulation research of the control systems for a discrete, stationary linear model with signal bounds described by equations (1)-(2), the control systems described by equations (3)-(8) the quality indicator in the form of (9)-(11), the time horizon $N=1000$ and the sampling period is one day. Tuning of the control system is based on a the bicriterial optimization task using SPEA2 (improved version of Strength Pareto Evolutionary Algorithm) and trapezoidal demand signal plotted in Fig. 8 and 9. On the basis of the results we try to evaluate: how does the controller structure impact on the properties of the inventory control system.

To solve the optimization problem (17) a SPEA2 was used with parameters: population size 500 for all A, A' and B, maximal number of generations 50 for A' and B, 400 for A.

In order to see the impact of the delay between ordering products and delivering it to the inventory $-\tau$ on the results of optimization task and the performance of the control system, simulations were carried out for three values of $\tau: 28,14$ and 2 . First, an analysis of the objective function plots has been conducted. Pareto front with shortages cost $j_{1}$ and holding cost $j_{2}$ is depicted in Fig. 5 for 3 delay values.

It can be noticed from Fig. 5 that almost all solutions for A control system are dominated by solutions for B control system for all considered delays except from solutions for $j_{1}<2$ and

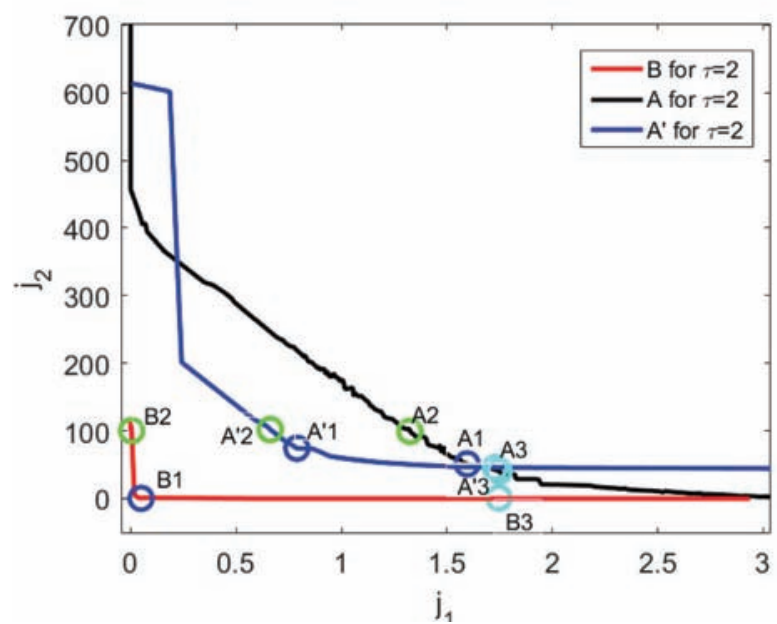

Fig. 6. Pareto front and selected points for inventory control system for $\tau=2$

Rys. 6. Front Pareto oraz wybrane punkty dla systemu sterowania dla $\tau=2$ 


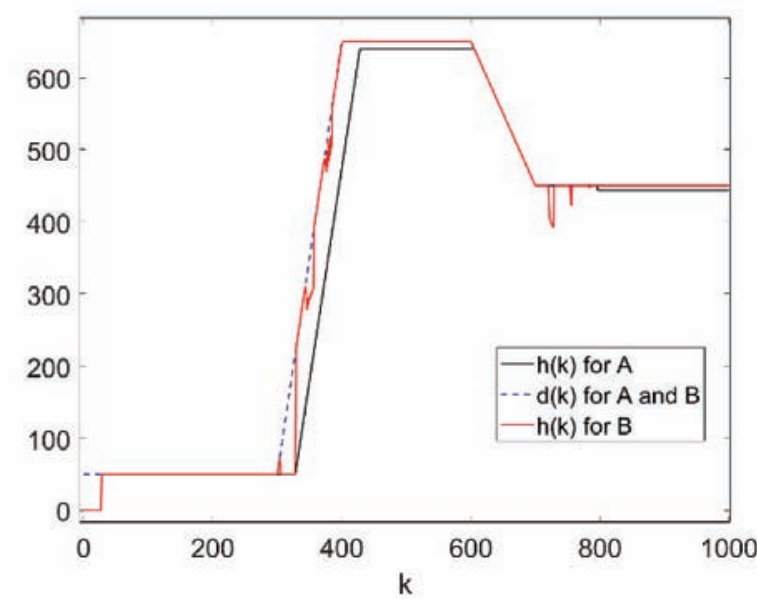

Fig. 7. System response - purchased products $h(k)$ and customer demand $\mathrm{d}(\mathrm{k})$ for $\mathrm{A} 4, \mathrm{~B} 4$ for $\mathrm{\tau}=\mathbf{2 8}$

Rys. 7. Odpowiedź układu - zakupione produkty $h(k)$ oraz zapotrzebowanie klientów d(k) dla A4, B4 dla $\tau=28$

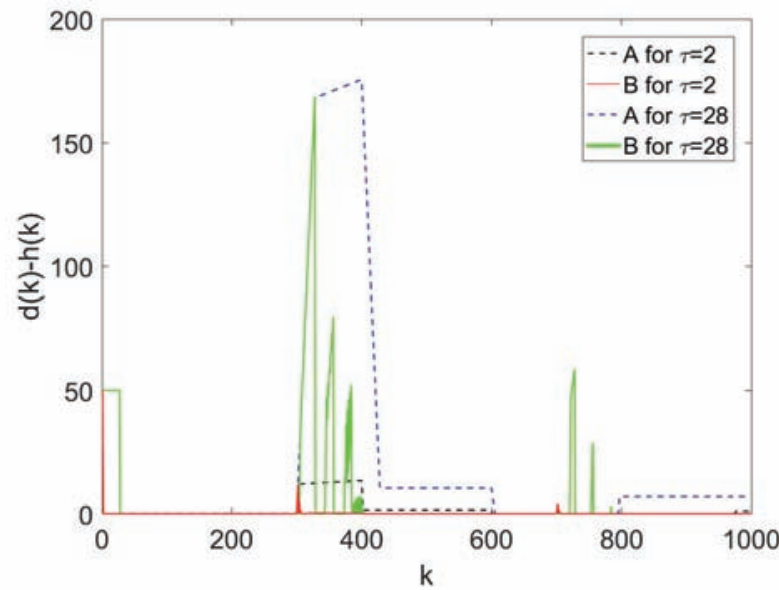

Fig. 8. System response - difference between customer demand $d(k)$ and purchased products $\mathrm{h}(\mathrm{k})$ for $\mathrm{A} 4, \mathrm{~B} 4$ for $\tau=\mathbf{2 8}$ and $\mathrm{A} 1, \mathrm{~B} 1$ for $\tau=\mathbf{2}$ Rys. 8. Odpowiedź układu - różnica pomiędzy zapotrzebowaniem klientów $\mathrm{d}(\mathrm{k})$, a zakupionymi produktami $\mathrm{h}(\mathrm{k})$ dla A4, B4 dla $\mathrm{\tau}=28 \mathrm{i} \mathrm{A} 1, \mathrm{~B} 1 \mathrm{dla} \tau=2$

$j_{2}>5200$ for $\tau=28$ where the opposite situation can be seen. However, due to considerably high value of holding cost, i.e. the value $j_{2}$, these solutions are not relevant for practical reasons. On the other hand, A', which is A with work-in-progress mechanism, achieves smaller cost function values $j_{1}$ and $j_{2}$. Although results for $\mathrm{A}$ and $\mathrm{B}$ are also relatively close to each other for small delay $\tau=2$. It means that the phenomenon of shortages and high holding costs occurs less in B than in A and A'. Next step of the analysis requires selection of points in the Pareto front plots (Fig. 5 and Fig. 6) on the basis of three criteria.

Three points were chosen among the solutions space for $\tau=2$ and $\tau=28$. Selected points were chosen by three criterions (see Table 1 and 2):

1) $\min \left(100 j_{1}+j_{2}\right): \mathrm{A} 1, \mathrm{~B} 1, \mathrm{~A}^{\prime} 1$ for $\tau=2$ and $\mathrm{A} 4, \mathrm{~B} 4, \mathrm{~A}^{\prime} 4$ for $\tau=28-$ marked by blue circles;

2) $j_{2} \approx$ const $\approx 100:$ A2,B2, A'2 for $\tau=2$ and $j_{2} \approx$ const $\approx 2900$ : A5, B5, A'5 for $\tau=28$ - marked by green circles;

3) $j_{1} \approx$ const $\approx 1.8: \mathrm{A} 3, \mathrm{~B} 3, \mathrm{~A}^{\prime} 3$ for $\tau=2$ and $j_{2} \approx$ const $\approx 17.3$ : A6, B6, A'6 for $\tau=28$ - marked by cyan circles.

After points selection, it is possible to make a simulation research of responses of presented inventory control systems: $h(k)$, $y(k), d(k)-h(k)$.
Table 1. Selected optimization results using SPEA2 Algorithm to $A$ Control System

Tabela 1. Wybrane wyniki optymalizacji z wykorzystaniem algorytmu SPEA2 do systemu sterowania A

\begin{tabular}{|c|c|c|c|c|c|}
\hline Point & $j_{1}$ & $j_{2}$ & $k_{1}$ & $k_{2}$ & $k_{3}$ \\
\hline \multicolumn{5}{|c|}{$\tau=2$} \\
\hline A1 & 1.60 & 51.1 & 0.997 & 0.131 & 804 \\
\hline $\mathbf{A 2}$ & 1.33 & 99.3 & 0.995 & 1.34 & 477 \\
\hline A3 & 1.75 & 40.3 & 0.997 & 0.022 & 318 \\
\hline \multicolumn{7}{|c|}{$\tau=28$} & \\
\hline A4 & 20.6 & 394 & 0.983 & 0.808 & 4459 \\
\hline A5 & 9.58 & 2918 & 0.887 & 44.96 & 27775 \\
\hline A6 & 17.3 & 1323 & 0.939 & 16.6 & 27495 \\
\hline
\end{tabular}

Table 2. Selected optimization results using SPEA2 Algorithm to B Control System

Tabela 2. Wybrane wyniki optymalizacji z wykorzystaniem algorytmu SPEA2 do systemu sterowania B

\begin{tabular}{|c|c|c|c|c|c|}
\hline Point & $j_{1}$ & $j_{2}$ & $k_{1}$ & $k_{2}$ & $k_{3}$ \\
\hline \multicolumn{6}{|c|}{$\tau=2$} \\
\hline B1 & 0.0489 & 0.225 & 5.20 & 0.238 & 0.524 \\
\hline B2 & 0.00423 & 100 & 1.95 & 1.488 & 0.0081 \\
\hline B3 & 1.78 & 0.006 & 4.94 & 0.253 & 0.283 \\
\hline \multicolumn{6}{|c|}{$\tau=28$} \\
\hline B4 & 3.91 & 385 & 68.7 & 0.0240 & 0.825 \\
\hline B5 & 1.79 & 2879 & 97.1 & 0.015 & 0.995 \\
\hline B6 & 17.3 & 50.9 & 28.1 & 0.529 & 0.219 \\
\hline
\end{tabular}

Table 3. Selected optimization results using SPEA2 Algorithm t A' Control System

Tabela 3. Wybrane wyniki optymalizacji z wykorzystaniem algorytmu SPEA2 do systemu sterowania A'

\begin{tabular}{|l|c|c|c|c|c|}
\hline Point & $j_{1}$ & $j_{2}$ & $k_{1}$ & $k_{2}$ & $k_{3}$ \\
\hline \multicolumn{5}{|c|}{$\tau=2$} \\
\hline A'1 & 0.788 & 74.3 & 3.00 & 0.0259 & 21.1 \\
\hline A'2 & 0.662 & 102 & 3.00 & 0.107 & 8.83 \\
\hline A'3 & 1.73 & 46.1 & 2.99 & 0.0574 & 10.5 \\
\hline \multicolumn{7}{|c|}{$\tau=28$} & 28.5 & 28.4 & 377 \\
\hline A'4 & 10.8 & 801 & 27.5 & 742 & 200 \\
\hline A'5 & 2.33 & 2918 & 28.0 & 8.50 & 308 \\
\hline A'6 & 17.3 & 478 & 28.0 \\
\hline
\end{tabular}




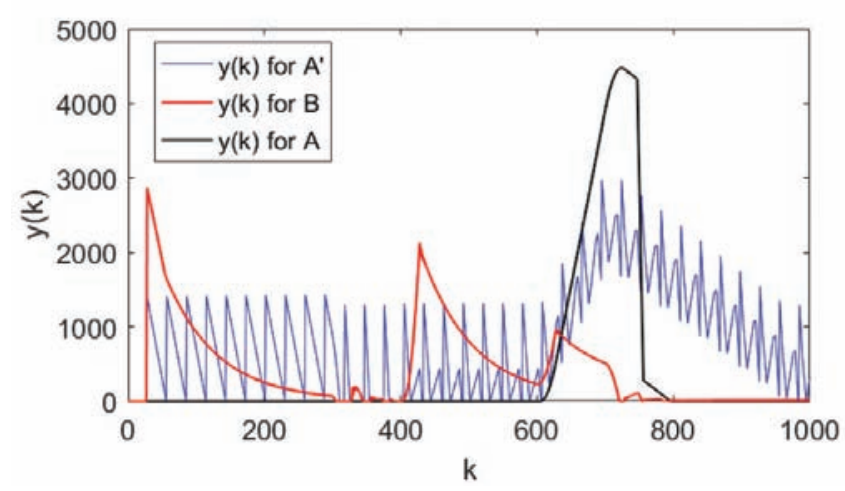

Fig. 9. System response - the stock level $y(k)$ for $A 4, A^{\prime} 4, B 4$ for $\tau=28$ Rys. 9. Odpowiedź układu - poziom zapasów y(k) dla A4, A’4, B4 dla $\tau=28$

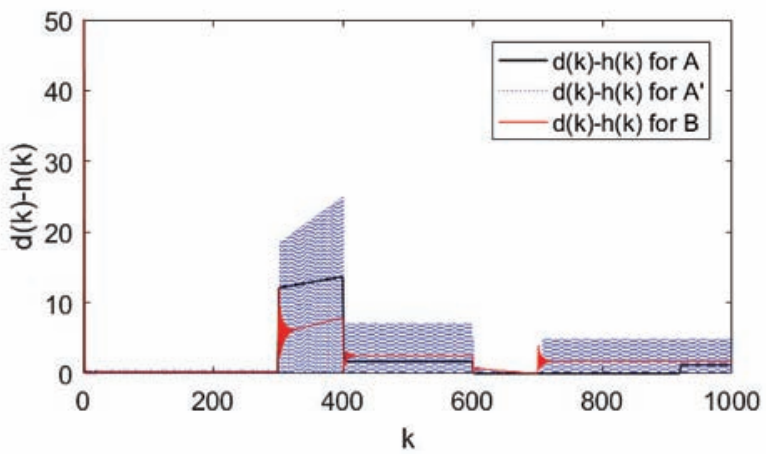

Fig. 10. System response - difference between customer demand $d(k)$ and purchased products $h(k)$ for $A 3, A^{\prime} 3, B 3$ for $\tau=2$

Rys. 10. Odpowiedź układu - różnica pomiędzy zapotrzebowaniem klientów d(k), a zakupionymi produktami h(k) dla A3, A'3, B3 dla $\tau=2$

In Fig. $7 h(k)$ is showed. It represents number of purchased products. In ideal control system $h(k)=d(k)$ but deviations occured because of the unknown in advance demand, delay $\tau$ and the criterion of minimizing inventory stocks $j_{2}$. In Fig. 8 can be seen precisely difference between selled goods in two systems with different two shipping delays: $\tau=2$ and $\tau=28$.

Beacause of broad simulation horizon and small delay $(\tau=2)$, a plot with $h(k)$ is showed almost demand $h(k) \approx d(k)$. There is no visible difference between $d(k), h_{A}(k), h_{B}(k)$ for points A3, B3 and $\tau=2$. This is because of incomparably small deviation value compared to demand. For this reason, we show Fig. 8 which

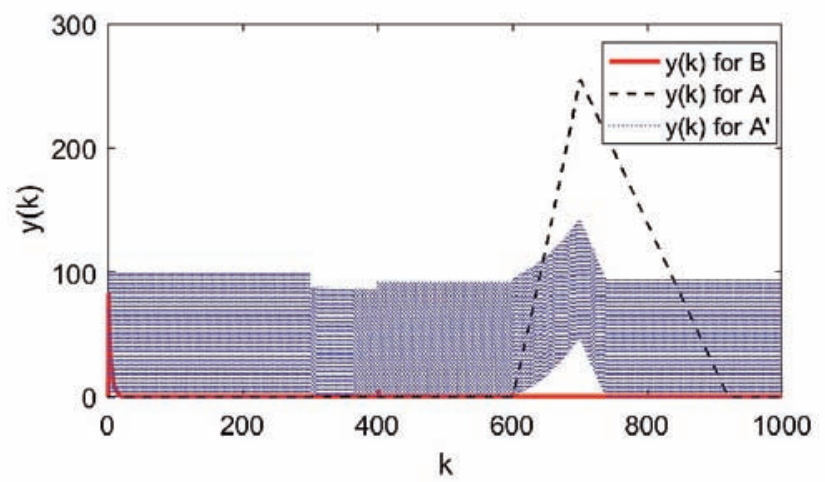

Fig. 11. System response - the stock's level $y(k)$ for $A 3, A^{\prime} 3, B 3$ for $\tau=2$ Rys. 11. Odpowiedź układu - poziom zapasów y(k) dla A3, A'3, B3 dla $\tau=2$ presents the difference of the two values: customer demand minus the current number of purchased products.

It is also necessary to take into account $y(k)$ which represents number of accumulated stocks in the inventory. Inventory control system which generates higher peak stocks levels as a result of demand decrease is definitely worst than one with lower stocks level. This situation can be seen in Fig. 9 - for $k \in(600$, 700) system $\mathrm{B}$ has the peak value - 970, A - 4500 and A' 3000. After including work-in-progress mechanism in A, it can be seen that $y(k)$ has the shape of saw and there is no single hudge signal like in A, but classical saw-shaped stock level. In the Fig. 9, you can see that B and A aims to achieve zero level of stocks for $\tau=28$ and manage it for $k>800$.

On the basis of defintion of $j_{1}$ it may be concluded that its difference should equal zero for $k=\tau, \tau+1, \ldots, N$ where $N$ is the length of the time horizon. In Fig. 8 and 10 it is clearly seen that difference between demand and the number of purchased products of the two systems is almost the same until $k \leq 300$. We can say that on response to step demand with level 50 at the time zero of two systems is similar, but complety different responses occur for linearly increasing demand - interval $k \in$ $(300,400)$.

Tables 1-3 consist of solutions for selected points. They shown that for the same shortage cost, the holding cost is the smallest for system B, what we can observe in the Fig. 11. Furthermore, taking into consideration the interval in the Fig. 11 $k \in(300,400)$ when $d(k)$ rapidly changing (from 50 to 650 ), it is an evidence that B manage to cope with fast amplification of demand with minimal stock level. On the contrary, A and A' have almost the same value of $j_{1}$ as $\mathrm{B}$, but significantly higer values of the $j_{2}$ indicator (holding cost), i.e.: $\mathrm{A}-40.3, \mathrm{~A}^{\prime}-46.1$, where for $\mathrm{B} j_{2}=0.006$.

\section{Conclusions}

Advantage of Proportional-derivative Inventory Control System with Smith predictor and adaptive reference stock level over Perpetual Inventory System with adaptive order level is clearly visible through steps of the comparison process. First step of analysis shows significant advantage of B over A for every value of assumed delay between ordering products and delivering it to the inventory. Comparison of Pareto front plots was made for the same value of the delay and the same demand function. The simulations results shows that system proposed by the authors have better values of optimization indicators presented in table 1 and 2 for all criterions described in section 5.: for criterion $\min \left(100 j_{1}+j_{2}\right)-j_{1}$ and $j_{2}$ are smaller, for criterion $j_{2}=$ const $-j_{1}$ is smaller, and for criterion $j_{1}=$ const $-j_{1}$ is smaller.

In order to finalize the comparison, we analyse figures with number of purchased products, the stock level response and pointed out the difference of market demand and currently purchased products. What is more, Proportional-Derivative Inventory Control System with Smith predictor and adaptive reference stock level has better inventory stocks level value smaller for $\tau=28$ and $\tau=2$ taking into account the whole time horizon. Proportional-Derivative Inventory Control System with Smith predictor and adaptive reference stock level - for each delay and is characterized by the lowest value of $j_{1}$ and $j_{2}$. The overall conclusions show a advantage of $\mathrm{B}$ over $\mathrm{A}$ and $\mathrm{A}^{\prime}$ in certain periods: for all $j_{1}, j_{2}(\tau=2, \tau=14)$ or almost all for $\tau=28$. As a result of this, the inventory holding cost is larger and shortages are more frequent and longer for the order-up-to policy A and A' than it is for PD with Smith predictor approach in these periods. 
The results demonstrate the capabilities of the evolutionary optimization approach to generate true and well distributed pareto-optimal non-dominated solutions.

In conclusion, adding work-in-progress mechanism to perpetual inventory control system results in better system performance in some specific periods shown in Figs. 5 and 6 , but the results are still dominated by results for PD with Smith predictor approach.

\section{Bibliography}

1. Fonseca C.M., Fleming P.J., Genetic Algorithms for Multiobjective Optimization: FormulationDiscussion and Generalization. In ICGA Vol. 93, 1993, 416-423.

2. Horn J., Nafpliotis N., Goldberg D.E., A niched Pareto genetic algorithm for multiobjective optimization. In Evolutionary Computation, 1994. IEEE World Congress on Computational Intelligence. 1994, Proceedings of the First IEEE Conference on (82-87) IEEE.

3. Srinivas N., Deb K., Muiltiobjective optimization using nondominated sorting in genetic algorithms, "Evolutionary computation", 2(3), 1994, 221-248.

4. Zitzler E., Thiele L., An evolutionary algorithm for multiobjective optimization: The strength Pareto approach. TIK-Report, 1998.

5. Zitzler E., Thiele L., Multiobjective evolutionary algorithms: a comparative case study and the strength Pareto approach. IEEE Transactions on Evolutionary Computation 3.4, 1999, 257-271.

6. Zitzler E, Laumanns M., Thiele L., Spea2: Improving the strength Pareto evolutionary algorithm. Technical Report 103, Gloriastrasse 35, CH-8092 Zurich, Switzerland, May 2001, 95-100.

7. Gadhvi B., Savsani V., Patel V., Multi-Objective Optimization of Vehicle Passive Suspension System Using NSGA-II, SPEA2 and PESA-II, "Procedia Technology", 2016, 23, 361-368.

8. Khajwaniya K.K., Tiwari V., Satellite image denoising using Weiner filter with SPEA2 algorithm. In Intelligent Systems and Control (ISCO), 2015 IEEE 9th International Conference on (1-6). IEEE.

9. Adham A.M., Mohd-Ghazali N., Ahmad R., Performance optimization of a microchannel heat sink using the Improved Strength Pareto Evolutionary Algorithm (SPEA2), "Journal of Engineering Thermophysics", 2015, 24(1), 86-100.

10. De Tommasi L., Beelen T.G., Sevat M.F., Rommes J., ter Maten E.J.W., Multi-objective optimization of $R F$ circuit blocks via surrogate models and NBI and SPEA2 methods. In Progress in Industrial Mathematics at ECMI 2010, 195-201, 2012, Springer Berlin Heidelberg, doi: 10.1007/978-3-642-25100-9_23.

11. Amouzgar K., Cenanovic M., Salomonsson K., Multi-objective optimization of material model parameters of an adhesive layer by using SPEA2. In 11th World Congress of Structural and Multidisciplinary Optimization (WCSMO-11), 2015, 249-254.

12. Berrocal-Plaza V., Vega-Rodríguez M.A., Sánchez-Pérez J.M., Optimizing the Location Areas Planning in the SUMATRA Network with an Adaptation of the SPEA2 Algorithm. In International Conference on Computer Aided Systems Theory, 243-250, 2013 Springer Berlin Heidelberg.

13. Tersine R.J., Principles of inventory and materials management, 1994.
14. Chołodowicz E., Orłowski P., Dynamiczny dyskretny model systemu magazynowego ze zmiennym w czasie opóźnieniem, „Logistyka”, Vol. 4, 2015, 28-32.

15. Ouyang L.Y., Wu K.S., Cheng M.C., An inventory model for deteriorating items with exponential declining demand and partial backlogging. "Yugoslav Journal of Operations Research", 2013,15(2).

16. Sarkar B., A production-inventory model with probabilistic deterioration in two-echelon supply chain management. "Applied Mathematical Modelling", 37(5), 2013, 3138-3151.

17. Ignaciuk P., Bartoszewicz A., Dead-beat and reaching-law-based sliding-mode control of perishable inventory systems, Bulletin of the Polish Academy of Sciences: Technical Sciences, Vol. 59, No. 1, 2011, 39-49, DOI: 10.2478/v10170-011-0023-1.

18. Ignaciuk P., Bartoszewicz A., LQ optimal sliding mode supply policy for periodic review inventory systems, IEEE Transactions on Automatic Control, Vol. 55, No. 1, 2010, 269-274, DOI: 10.1109/TAC.2009.2036305.

19. Leśniewski P., Bartoszewicz A., Non-switching reaching law based discrete time quasi-sliding mode control with application to warehouse management problem, IFAC Proceedings Volumes. Vol. 47, No. 3, 2014, 4589-4594, DOI: $10.3182 / 20140824-6-Z A-1003.00181$.

20. Ignaciuk P., Bartoszewicz A., Linear-quadratic optimal control of periodic-review perishable inventory systems, IEEE Transactions on Control Systems Technology, Vol. 20, No. 5, 2012, 1400-1407, DOI: 10.1109/ TCST.2011.2161086.

21. Chołodowicz E., Orłowski P.: Sterowanie przepływem towarów w magazynie z wykorzystaniem predyktora Smitha, Pomiary Automatyka Robotyka, vol. 19, no.3, 2015, 55-60.

22. Chołodowicz E., Orłowski P.: A periodic inventory control system with adaptive reference stock level for long supply delay, Measurement Automation Monitoring, vol. 61 , no. $12,2015,568-572$.

23. Abrahamowicz E., Orłowski P., Zastosowanie regulatora ułamkowego rzędu PD do automatycznego sterowania zamówieniami dla magazynu ze zmiennym w czasie opóźnieniem dostaw, Pomiary Automatyka Robotyka, R. 20, Nr 2/2016, 5-10, DOI: 10.14313/PAR_220/5.

24. Orłowski P., Analiza dwukryterialnego problemu optymalizacji w zastosowaniu do automatycznego sterowania systemem zamówień $w$ magazynie $z$ dużymi opóźnieniami dostaw z wykorzystaniem regulatora feedback-feedforward z predyktorem Smitha. Przegląd Elektrotechniczny, ISSN 0033-2097, 2016.

25. Grzyb S., Orlowski P., Feedback control system with PWA load dependent reference buffer occupancy for congestion control in computer networks. "Przegląd Elektotechniczny", No. 46, 2016, 42-45.

26. Dejonckheere J., Disney S.M., Lambrecht M.R., Towill D.R., Measuring and avoiding the bullwhip effect: A control theoretic approach. "European Journal of Operational Research", 147(3), 2002, 567-590.

27. Riddalls C.E., Bennett S., The stability of supply chains. "International Journal of Production Research". 40(2), 2002, 459-475.

28. Karlin S., One stage inventory models with uncertainty. In: Karlin S., Scarf H., Studies in the mathematical theory of Inventory and Production, Stanford University Press, 1958, 109-134. 
29. Boccadoro M., Martinelli F., Valigi P., Supply chain management by H-infinity control. IEEE Transactions on Automation Science and Engineering, 5(4), 2008, 703-707.

30. Ch Y., You F., Wassick J.M., Agarwal A., Simulation-based optimization framework for multi-echelon inventory systems under uncertainty. "Computers \& Chemical Engineering", 2015, 73, 1-16.
31. Fattahi P., Hajipour V., Nobari A., A bi-objective continuous review inventory control model: Pareto-based meta-heuristic algorithms. "Applied Soft Computing", 2015, 32, 211-223.

32. Coello C.A.C., Van Veldhuizen D.A., Lamont G.B., Evolutionary algorithms for solving multi-objective problems. 2002, Vol. 242, New York: Kluwer Academic.

Analiza porównawcza systemu sterowania ciągłego oraz z regulatorem PD i predyktorem Smitha dla różnych opóźnień dostaw z zastosowaniem metod optymalizacji dwukryterialnej i SPEA2

Streszczenie: W pracy przyjęto dyskretny, stacjonarny, dynamiczny model systemu magazynowego ze stałym w czasie opóźnieniem dostaw. Głównym celem jest przeprowadzenie analizy porównawczej dwóch systemów automatycznego sterowania zamówieniami: ciągłego systemu sterowania magazynem z adaptacyjnym poziomem zamówienia (ang. Perpetual Inventory System with adaptive order level) oraz systemu sterowania magazynem z regulatorem proporcjonalno-różniczkującym oraz predyktorem Smitha z adaptacyjnym poziomem referencyjnym zapasów dla trzech różnych opóźnień dostaw. Optymalne nastawy układów regulacji zostały dobrane za pomocą algorytmu ewolucyjnego dla problemów optymalizacji wielokryterialnej: SPEA2 (ang. Strength Pareto Evolutionary Approach). W symulacji uwzględniono dwa kryteria minimalizacji: koszt utrzymania zapasów (ang. Holding Cost) oraz koszt niedoboru zapasu (ang. Shortage Cost). Wyniki badań symulacyjnych zaprezentowano za pomocą wykresów oraz tabel w środowisku MATLAB/Simulink.

Keywords: systemy zarządzania zapasami, optymalizacja, optymalizacja wielokryterialna, SPEA2, system sterowania, predyktor Smitha

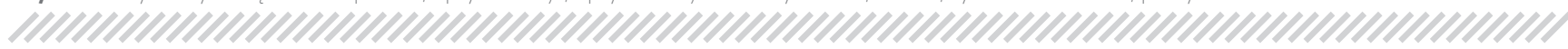

\section{Ewelina Chołodowicz \\ cholodowicz.ewelina@gmail.com}

Student at the Faculty of Electrical Engineering at West Pomeranian University of Technology Szczecin. Winner of the Ministry of Science and Higher Education scientific scholarship for students, the Mayor of Szczecin scholarship for students and the "West Pomeranian Talents - Regional Scholarship System". Recent research topics are modelling, simulation and control of dynamic systems.

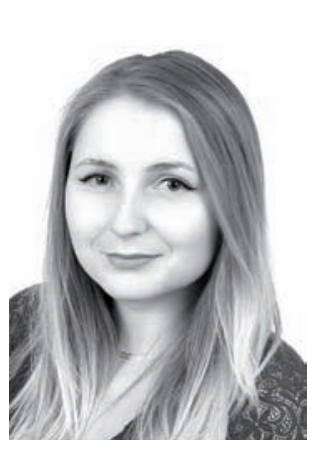

\section{Przemysław Orłowski, PhD, DSc} przemyslaw.orlowski@zutedu.pl

Associate Professor in the Department of Control and Measurements at West Pomeranian University of Technology Szczecin. The research topics are concerned on the analysis and synthesis of control systems, discrete-time systems, time-varying systems, nonlinear systems, uncertain systems and hybrid systems. 